\title{
Waziristan Ophiolite: A back-arc basin caught in continental collision, Waziristan, NW Pakistan
}

\author{
Said Rahim Khan†*, M Qasim J an‡, Tahseenullah Khan† and M Asif Khan§ \\ † Geoscience Laboratory, Geological Survey of Pakistan, Shahzad Town, Islamabad, PAKISTAN \\ ¥ Department of Geology, University of Peshawar, Peshawar, PAKISTAN \\ $\$$ National Centre of Excellence in Geology, University of Peshawar, Peshawar, PAKISTAN
}

* To whom correspondence should be addressed.E-mail:srk1953@yahoo.com

\begin{abstract}
The western margin of the Indian plate is a classical example of continent-continent collision. The Afghanistan-Kabul-India continental blocks are here welded to each other by a network of sutures defined by the occurrence of ophiolites. The Waziristan Ophiolite (WO) is one of a series of ophiolites sandwiched between the western margin of the Indian plate and Afghanistan block. It is highly dismembered, but contains all the segments of an ideal ophiolite suite. It can be internally divided into three nappes which, from east to west, are: Vezhda Sar nappe, comprising entirely of pillow basalts; Boya nappe, a tectonic melange with an intact ophiolite section in the basal part at Mami Rogha; and Datta Khel nappe, consisting of sheeted dykes with variable proportions of other components.

The intact ophiolite section consists of 1) basal ultramafics followed upward by 2) isotropic gabbros, and 3) pillow basalts, intercalated with and capped by pelagic sediments (chert, shale, limestone) (Figure 1). Isolated mafic dykes (doleritic), characterised by chilled margins, intrude all types of ophiolitic rocks, except the pillow basalts of Vezhda Sar nappe. Trondhjemites mostly intrude the ultramafics and rarely gabbroic rocks. Layered gabbros, missing in the ophiolite section, are sporadically distributed as fault-bounded blocks in the two western nappes.
\end{abstract}

The ophiolite is thrust eastwards onto the Indian plate sediments, rather than beneath these sediments as reported. Regionally, the Main Waziristan Thrust (MWT) trends northsouth and dips towards west. Local changes in the trend of the MWT (from N-S to E-W) and dip (W to N) occurs north of BoyaMohammad Khel, which have been effected by later east-west trending strike-slip faults. Additional field data like the intact ophiolite section with base towards east and top towards west, and deposition of the Tertiary sediments on top of the ophiolite to the west, clearly support overthrusting of the ophiolite onto the sediments of the Indian plate to the east.
Radiolarian fauna (Tithonian-Valanginian) suggests Late Jurassic or older age for the formation of the WO. The presence of tectonic blocks of Campanian limestone (Parh Group) in the melange and coupling of the ophiolite with Maastrichtian shale suggest post Maastrichtian, most probably Palaeocene, emplacement of the ophiolite. A sequence of Early Eocene to Middle Eocene sediments unconformably overlying the WO, supports the Palaeocene emplacement of the ophiolite.

On the multi-element variation diagram, the geochemical data sets of the Waziristan ophiolitic rocks, display similar patterns, as would be expected in comagmatic rocks. Higher LILE/HFSE ratios and slight or no depletion of $\mathrm{Nb}$ characterise these rocks. The HFSE display a flat pattern similar to mid-ocean ridge basalt, whereas the LILE, particularly $\mathrm{Rb}$ and Ba, mark prominent positive spikes. The wide compositional variation of the ophiolitic rocks (volcanics: basalt to rhyolite, dykes: basalt to andesite, gabbros: gabbro to gabbro-diorite), with transitional characteristics between MORB and IAT, negates origin of the ophiolite in a typical mid-ocean ridge environment. A fore-arc origin for the ophiolite cannot be advocated due to absence of rocks typical of fore-arcs, particularly bonninites which are common in active fore-arcs of the present day, e. g., Mariana. However, strong negative $\mathrm{Nb}$ anomaly characteristic of islandarc rock suites is also not found in these rocks. This raises the possibility that these rocks might have originated in a back-arc basin setting. The high LILE/HFSE ratios in these rocks suggest that crustal components along subduction zone were added to the overlying mantle by rising fluids. The back arc basin setting is suggested by several chemical traits of the ophiolitic rocks: 1) transitional chemistry between MORB and island arc rocks, 2) enrichment in LILE (such as $\mathrm{Ba}, \mathrm{Rb}$ ) and depletion in HFSE (such as $\mathrm{Zr}$ or $\mathrm{Nb}$ ), low negative $\mathrm{Nb}$ anomaly, and lower $\mathrm{MgO}$ than MORB glasses. It is concluded that the Waziristan ophiolitic rocks are comagmatic and probably owe their origin to a back-arc basin or supra-subduction zone setting. 


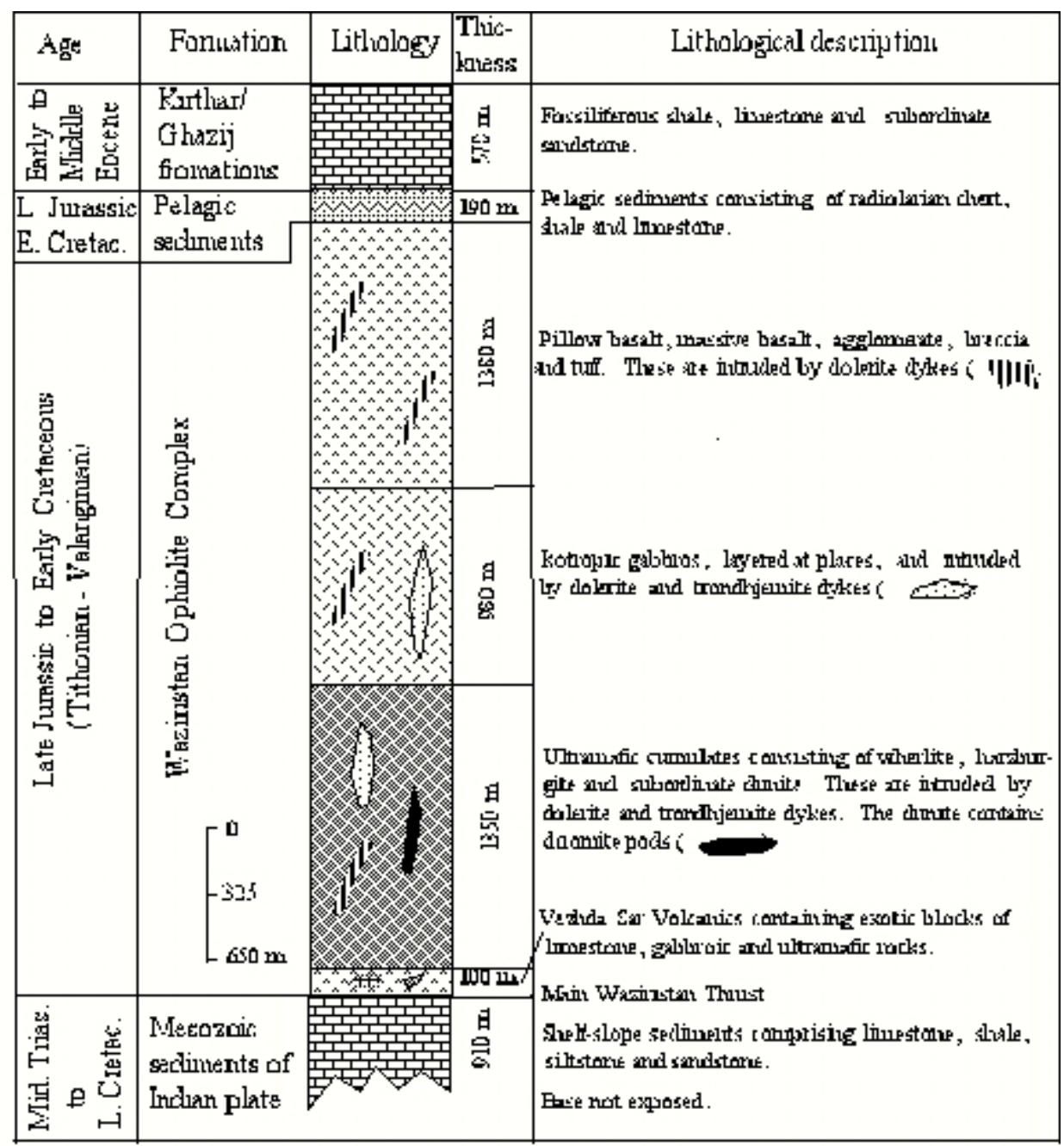

FIGURE 1. A schematic litho - stratigraphic column of the Waziristan Ophiolite at Mami Rogha. The dykes are not according to scale 